\title{
HUBUNGAN KUALITAS PRODUK, HARGA, DISTRIBUSI DAN STRATEGI PROMOSI TERHADAP KEPUTUSAN MEMBELI KORAN JUALBELI
}

\author{
Doni Wihartika \\ Dosen Fakultas Ekonomi Fakultas Ekonomi
}

\begin{abstract}
ABSTRAK
Penelitian ini dilakukan dengan tujuan untuk menguji hubungan kualitas produk, harga, distribusi dan strategi promosi Koran JualBeli terhadap keputusan membeli Koran JualBeli. Perumusan masalah sebagai berikut: (1) Apakah kualitas produk berhubungan dengan keputusan pembelian produk Koran JualBeli? (2) Apakah harga berhubungan dengan keputusan pembelian produk Koran JualBeli? (3) Apakah distribusi berhubungan dengan keputusan pembelian produk Koran JualBeli? (4) Apakah strategi promosi berhubungan dengan keputusan pembelian produk Koran JualBeli? (5) Apakah kualitas produk, harga, distribusi dan strategi promosi berhubungan dengan keputusan pembelian produk Koran JualBeli. Penelitian ini dilakukan di lokasi DTX Bogor, Jawa Barat. Dari hasil penelitian menunjukkan bahwa produk (X1) dan strategi promosi (X4) secara parsial tidak berpengaruh terhadap keputusan membeli $(\mathrm{Y})$, sedangkan harga $(\mathrm{X} 2)$ dan distribusi (X3) secara parsial memiliki pengaruh terhadap keputusan membeli (Y).
\end{abstract}

Kata kunci: Koran JualBeli, Keputusan Membeli, Distribusi, Strategi Promosi

\section{ABSTRACT}

Formulation of the problem as follows: (1) Has product quality related with buying decision on Koran JualBeli? (2) Has price related with buying decision on Koran JualBeli? (3) Has distribution related with buying decision on Koran JualBeli? (4) Has promotion strategy related with buying decision on Koran JualBeli? (5) Are there relationships between product quality, price, distribution and promotion strategy of Koran JualBeli with buying decision of Koran JualBeli? The place of research is in DTX which is located in Bogor, West Java. The result shows that the product (X1) and the promotion strategy (X4) are not partially correlated with the buying decision $(Y)$, while the price $(X 2)$ and the distribution (X3) are partially correlated with the buying decision (Y).

Keywords: Koran JualBeli, Buying Decision, Distribution, Promotion Strategy

\section{PENDAHULUAN}

Pergeseran dari era pertanian menuju era industrialisasi, yang diikuti oleh era informasi disertai dengan banyaknya penemuan baru di bidang teknologi informasi serta globalisasi ekonomi telah membawa peradaban manusia kedalam suatu interaksi sosial baru yang tidak pernah terbayangkan sebelumnya. Globalisasi di bidang media dan hiburan juga telah mengubah karakter, gaya hidup dan perilaku masyarakat menjadi lebih kritis dan lebih peka terhadap rasa serta pasar pun menjadi semakin luas dan semakin global. Dampak dari globalisasi inilah sehingga kemudian pada tahun 1990-an dimulai era ekonomi baru yang mengintensifkan informasi dan kreativitas, populer disebut ekonomi kreatif karena digerakkan oleh sektor industri kreatif.

Salah satu subsektor dari industri berbasis kreativitas adalah periklanan. Subsektor ini meliputi segala kegiatan kreatif yang berkaitan dengan jasa periklanan (komunikasi satu arah dengan menggunakan

JIMFE (Jurnal Ilmiah Manajemen Fakultas Ekonomi)

Volume 2 No. 2 Tahun 2016, Hal. 51-57 
medium tertentu). Jasa periklanan ini meliputi proses kreasi, produksi dan distribusi dari iklan yang dihasilkan, misalnya: riset pasar, perencanaan komunikasi iklan, iklan luar ruang, produksi material iklan, promosi, kampanye relasi publik, tampilan iklan di media cetak (surat kabar, majalah) dan elektronik (televisi dan radio), pemasangan berbagai poster dan gambar, penyebaran selebaran, pamflet, edaran, brosur dan reklame sejenis, distribusi dan delivery advertising materials atau sample, serta penyewaan kolom.

Koran JualBeli adalah sebuah usaha kreatif dari perusahaan perseorangan DTX yang bergerak dalam subsektor periklanan dimana fokus usahanya sebagai jasa media cetak iklan di wilayah Bogor. Koran ini dijual dengan harga Rp3000,- dan keseluruhan isi materi koran berupa iklan. Terdapat dua jenis jasa iklan yang diberikan yaitu jasa iklan baris yang bersifat gratis dan diiklankan melalui SMS, dan iklan premium yaitu iklan yang memerlukan sejumlah biaya yang dibebankan kepada pengiklan sesuai dengan kualitas dan ukuran yang disepakati. Usaha ini mengandalkan jasa iklan premium sebagai produk inti (core product) dikarenakan pemasukan dari sektor iklanlah yang menggerakkan roda perusahaan, sedangkan produk Koran JualBeli hanya merupakan produk keluaran yang diharapkan (Expected Product) bagi perusahaan.

Peningkatkan volume penjualan Koran JualBeli dapat dicapai melalui peningkatan keputusan pembelian, upaya ini tentunya memerlukan strategi pemasaran dan positioning dalam memasarkan produk baik berupa barang maupun jasa.

\section{KAJIAN PUSTAKA}

\section{Produk}

Kotler dan Armstrong (2008: 347), menyatakan bahwa atribut produk adalah pengembangan suatu produk atau jasa yang melibatkan penentuan manfaat yang akan diberikan. Pengertian tersebut menunjukan bahwa suatu produk memiliki atribut atau dimensi berikut: merek produk, kemasan produk, label produk dan kualitas produk. Keempat atribut atau dimensi produk tersebut memberi pengaruh besar terhadap reaksi pengambilan keputusan bagi pelanggan. Sedangkan Tjiptono (2008: 103), menyatakan bahwa atribut produk adalah unsur-unsur produk yang dipandang penting oleh konsumen dan dijadikan dasar pengambilan keputusan pembelian. Atribut produk meliputi merek, kemasan, jaminan (garansi), pelayanan, dan sebagainya.

\section{Distribusi}

Kotler dan Armstrong (2008: 63), menyatakan bahwa tempat (distribusi) adalah kegiatan yang dilakukan perusahaan yang membuat produk supaya tersedia bagi pelanggan sasaran. Sedangkan Tjiptono (2008: 185), menyatakan bahwa pendistribusian dapat diartikan sebagai kegiatan pemasaran yang berusaha memperlancar dan mempermudah penyampaian barang dan jasa dari produsen ke konsumen sehingga penggunaannya sesuai dengan yang diperlukan (jenis, jumlah, harga, tempat dan saat dibutuhkan). Dalam penelitian ini distribusi adalah ketersediaan produk sehingga pelanggan dapat dengan mudah memperolehnya.

\section{Harga}

Philip Kotler (2004: 24), menyatakan bahwa harga dalam arti sempit merupakan jumlah uang yang ditagihkan untuk suatu produk atau jasa, sedangkan dalam arti luas adalah jumlah dari nilai yang dipertukarkan konsumen untuk manfaat memiliki atau menggunakan produk atau jasa. Sedangkan Buchari Alma (2007: 169) menyatakan bahwa harga adalah nilai suatu barang yang dinyatakan dengan uang. Dari definisi di atas terlihat, kebijakan mengenai harga umumnya bersifat sementara, berarti produsen harus mengikuti perkembangan harga di pasar dan 
harus mengetahui posisi produk dalam situasi pasar secara keseluruhan.

\section{Strategi Promosi}

Bauran promosi menurut Kotler dan Gary A. (2008) adalah ramuan khusus dari iklan pribadi, promosi penjualan dan hubungan masyarakat yang dipergunakan perusahaan untuk mencapai tujuan iklan dan pemasarannya. Menurut Santoso dan Tjiptono (2002: 229) promosi penjualan adalah bentuk persuasif langsung melalui penggunaan produk dengan segera dan/atau meningkatkan jumlah barang yang dibeli pelanggan. Melalui promosi penjualan, perusahaan dapat menarik pelanggan baru, mempengaruhi pelanggannya untuk mencoba produk baru, mendorong pelanggan membeli lebih banyak, menyerang aktifitas promosi pesaing, meningkatkan impulse buying (pembelian tanpa rencana sebelumnya), atau mengupayakan kerja sama lebih erat dengan pengecer.

\section{Keputusan Pembelian}

Menurut Mowen dan Minor (2001:322) minat beli adalah keinginan konsumen untuk berperilaku menurut cara tertentu dalam rangka memiliki, membuang, dan menggunakan produk dan jasa. Jadi, konsumen dapat membentuk keinginan untuk mencari informasi, memberitahu orang lain tentang pengalamannya dengan sebuah produk, membeli produk atau jasa tertentu, atau membuang produk dengan cara tertentu.

\section{Hipotesis}

Berdasarkan hal-hal di atas maka penulis mencoba merumuskan hipotesis sebagai berikut :

H1 : Variabel kualitas produk Koran JualBeli berhubungan dengan variabel keputusan pembelian Koran JualBeli.

H2 : Variabel harga Koran JualBeli berhubungan dengan variabel keputusan pembelian pada Koran JualBeli.

H3 : Variabel distribusi Koran JualBeli berhubungan dengan variabel keputusan pembelian Koran.

H4 : Variabel strategi promosi Koran JualBeli berhubungan dengan variabel keputusan pembelian Koran.

\section{OBJEK DAN METODE PENELITIAN Jenis Penelitian}

Jenis penelitian ini merupakan tipe penelitian eksplanatori dengan metode deskriptif statistik, penelitian bertujuan untuk menguji ada tidaknya hubungan dan pengaruh antara variabel-variabel bebas dan terikat yaitu antara variabel kualitas produk, harga, distribusi dan strategi promosi Koran JualBeli terhadap keputusan membeli Koran JualBeli.

\section{Objek Penelitian}

Dalam penelitian ini yang dijadikan objek penelitian adalah pelanggan Koran JualBeli, pemilihan objek penelitian didasari data pelanggan dan menggunakan tehnik random sampling.

\section{Unit Analisis}

Unit analisis merupakan tingkat agregasi data yang dianalisis dalam suatu penelitian. Unit analisis yang digunakan dalam penelitian ini adalah unit analisis organisasi, yaitu data yang dihasilkan berasal dari respon suatu organisasi tertentu.

\section{Lokasi Penelitian}

Penelitian dilakukan pada perusahaan DTX yang berlokasi di Jalan Raya Pajajaran No 127 Ruko SPBU, Kecamatan Bogor Tengah, Kota Bogor. Pemilihan DTX sebagai tempat penelitian dilakukan secara sengaja (purposive).

\section{Jenis dan Sumber Data Penelitian}

Jenis data dalam penelitian ini adalah jenis data kuantitatif yang merupakan data 
sekunder. Data sekunder adalah data yang diperoleh peneliti secara tidak langsung, tetapi diperoleh dari penyedia data yang digunakan peneliti dalam penelitian sebelumnya. Data sekunder dalam penelitian ini diperoleh dari DTX

\section{Metode Penarikan Sampel}

Metode penarikan sampel menggunakan metode stratified random sampling yaitu melakukan pengelompokan populasi kepada ciri-ciri yang homogen kemudian mengambil secara acak sederhana terhadap masing-masing kelompok secara proporsional atau non proporsional. Sampel penelitian meliputi sejumlah elemen/responden yang lebih besar dari persyaratan minimal sebanyak 30 elemen/responden. Menurut Guilford, 1987 dalam Supranto, 2006, semakin besar sampel (makin besar nilai $\mathrm{n}$ = banyaknya elemen sampel) akan memberikan hasil yang lebih akurat. Dalam penelitian ini jumlah populasi hanya sedikit maka sampel yang diambil adalah keseluruhan dari populasi, yakni 30 sampel.

\section{Uji Regresi Linier Berganda}

$$
Y=a+b_{1} X_{1}+b_{2} X_{2}+b_{3} X_{3}+b_{4} X_{4}+e
$$

$$
\begin{aligned}
& \text { Keterangan : } \\
& \mathrm{Y}=\text { Harga saham } \\
& \mathrm{a}=\text { Konstanta } \\
& \mathrm{X}_{1} \quad=\text { Kualitas produk } \\
& \mathrm{X}_{2} \quad=\text { Harga koran } \\
& \mathrm{X}_{3} \quad=\text { Distribusi koran } \\
& \mathrm{X}_{4} \quad=\text { Strategi promosi } \\
& b_{1} \text { sampai } b_{4}=\text { Koefisien regresi } \\
& \text { e } \quad=\text { Error term. }
\end{aligned}
$$

\section{HASIL PENELITIAN}

Hasil Analisis Deskriptif Data

The Results of Descriptive Analysis Data

\begin{tabular}{|l|c|r|r|}
\hline & N & Mean & \multicolumn{1}{c|}{ Std. Deviation } \\
\hline Produk & 56 & 3.8167 & .33434 \\
Harga & 56 & 4.1167 & .41530 \\
Distribusi & 56 & 4.1600 & .44613 \\
Promosi & 56 & 4.0067 & .36097 \\
Keputusan Membeli & 56 & 4.2200 & \\
Valid N (listwise) & 56 & & \\
\hline
\end{tabular}

(Sumber : Diolah SPSS)

\section{Deskriptif Statistik Variabel Penelitian}

Berdasarkan tabel 1 diketahui bahwa jumlah sampel data dalam penelitian ini adalah 30 sampel data.

- Kualitas Produk, berdasarkan sumber olahan data di atas (Tabel 1), terlihat persepsi responden terhadap variabel produk, yaitu nilai skor berkisar antara
$3,4 \sim<4,2$. Artinya responden menganggap kualitas produk sangat berpengaruh dalam membeli sebuah produk dengan skor rata-rata 3,8167.

- Harga, dari data di atas (Tabel 1), terlihat persepsi responden terhadap variabel harga, yakni nilai skor berkisar antara 3,4 $\sim<$,2. Artinya responden menganggap harga memiliki kriteria yang tinggi dalam 
mempengaruhi pengambilan keputusan untuk membeli dengan skor rata-rata 4,1167.

- Variabel distribusi, berdasarkan sumber olahan data di atas (Tabel 8), dapat terlihat persepsi responden terhadap variabel distribusi memiliki kriteria tinggi yakni nilai skor berkisar antara 3,4 $<$ 4,2 . Artinya responden menganggap distribusi produk memberikan pengaruhi bagi konsumen untuk memutuskan membeli sebuah produk dengan skor rata-rata 4,1600 yang termasuk kategori tinggi .

- Promosi, berdasarkan sumber olahan data diatas (Tabel 8), terlihat persepsi responden terhadap variabel promosi, yakni nilai skor berkisar antara 3,4 < 4,2. Artinya responden menganggap promosi sangat mengena sehingga konsumen memutuskan untuk membeli

sebuah produk dengan skor rata-rata 4,0067

- Variabel keputusan membeli, terlihat persepsi responden berada pada nilai skor berkisar antara 3,4 $<4,2$. Artinya responden menganggap keputusan pembelian mempengaruhi konsumen untuk memutuskan membeli sebuah produk dengan skor rata-rata 4.1638 .

Hasil uji statistik secara deskriptif terlihat bahwa rata-rata jawaban responden berada pada kategori yang tinggi. Hal ini menunjukkan bahwa responden memiliki pandangan yang baik terhadap keberadaan Koran JualBeli, sehingga dapat dikatakan Koran JualBeli sudah mulai dapat diterima oleh masyarakat sekitar.

\section{Analisa Korelasi}

Tabel 2

Hubungan Korelasi

Correlation Analysis

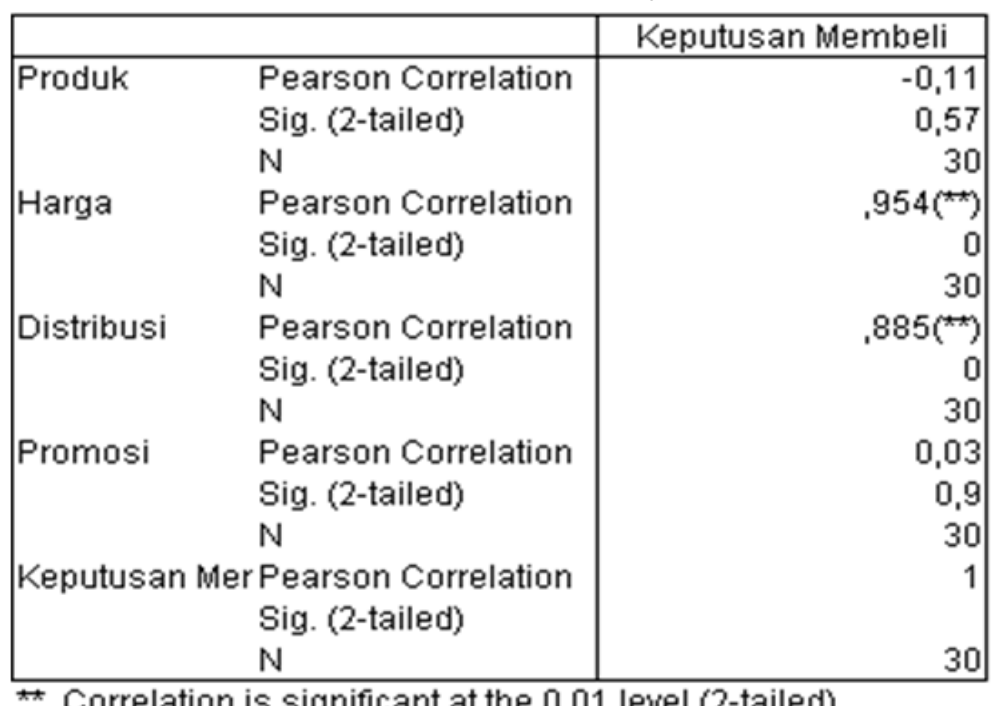

Correlation is significant at the 0.01 level (2-tailed).

(Sumber : Diolah SPSS)

Untuk melihat gambaran dengan program SPSS, maka korelasi antara variabel bebas dengan variabel terikat secara parsial sebagai berikut:

- Besar hubungan antara variabel produk dengan variabel keputusan pembelian yang dihitung dengan koefisien korelasi adalah -0,11, tanda negatif berarti menunjukkan terjadi korelasi yang negatif antara produk dan keputusan membeli.

- Besar hubungan antara variabel harga dengan variabel keputusan pembelian

JIMFE (Jurnal Ilmiah Manajemen Fakultas Ekonomi)

Volume 2 No. 2 Tahun 2016, Hal. 51-57 
yang dihitung dengan koefisien korelasi adalah 0,954. Tanda ** berarti signifikan.

- Besar hubungan antara distribusi dengan variabel keputusan pembelian yang dihitung dengan koefisien korelasi adalah 0,885 . Tanda $* *$ berarti signifikan.

- Besar hubungan antara promosi dengan variabel keputusan pembelian yang dihitung dengan koefisien korelasi adalah 0,03 .

Hubungan antara variabel produk dan keputusan menunjukkan tidak adanya hubungan. Hal ini terlihat dari nilai korelasinya yang negatif $(-0,11)$, kondisi ini menunjukkan bahwa kualitas produk tidak menjadi pertimbangan khusus dalam membeli Koran JualBeli. Variabel promosi, pengaruhnya dirasa tidak terlalu nyata terhadap keputusan membeli Koran JualBeli, nilainya hanya berkisar pada angka 0,03 yang menunjukkan hubungan yang sangat rendah. Keadaan ini dimungkinkan karena strategi promosi yang dilakukan belum terasa bagi pembeli atau bahkan dinilai belum efektif, oleh karenanya penerapan strategi promosi yang baru dapat menjadi peluang bagi perusahaan.

Variabel harga dan distribusi menunjukkan tingkat hubungan yang sangat kuat, faktor harga menjadi faktor yang paling tinggi dengan nilai mencapai $0,954(>0,08)$ mendekati nilai maximum 1 . Sedangkan faktor distribusi berada di urutan kedua dengan nilai hubungan mencapai 0,885 (> $0,80)$.

\section{SIMPULAN DAN SARAN}

\section{Simpulan}

1) Analisis perhitungan korelasi bentuk hubungan produk $\left(X_{1}\right)$ dengan keputusan membeli $(\mathrm{Y})$ sebesar -0,11. $\mathrm{Hal}$ ini menunjukkan adanya hubungan yang berlawanan (karena tanda negatif). Hasil analisa Sig. (2tailed) sebesar 0,57 dan dibandingkan dengan taraf signifikan 5\%, mempunyai hasil $0,57>0,01$, maka tidak signifikan artinya tidak terdapat pengaruh yang signifikan antara produk $\left(X_{1}\right)$ terhadap keputusan membeli $(\mathrm{Y})$.

2) Analisis korelasi harga $\left(X_{2}\right)$ dengan keputusan membeli $(\mathrm{Y})$ mempunyai bentuk hubungan sebesar 0,954. Hal ini menandakan adanya tingkat hubungan yang tinggi antara variabel harga dengan keputusan membeli. Hasil analisa Sig. (2-tailed) sebesar 0 dan dibandingkan dengan taraf signifikan 1\%, dapat diartikan sebagai: $0<0,01$, maka signifikan artinya terdapat pengaruh yang signifikan antara harga $\left(\mathrm{X}_{2}\right)$ terhadap keputusan membeli $(\mathrm{Y})$.

3) Analisis korelasi distribusi $\left(X_{3}\right)$ dengan keputusan membeli $(\mathrm{Y})$ mempunyai bentuk hubungan sebesar 0,885 . Hal ini menandakan adanya tingkat hubungan yang tinggi antara variabel distribusi dengan keputusan membeli. Hasil analisa Sig. (2-tailed) sebesar 0 dan dibandingkan dengan taraf signifikan $1 \%$, dapat diartikan sebagai: $0<0,01$, maka signifikan artinya terdapat pengaruh yang signifikan antara distribusi $\left(X_{3}\right)$ terhadap keputusan membeli $(\mathrm{Y})$.

4) Analisis korelasi strategi promosi $\left(X_{4}\right)$ dengan keputusan membeli $(Y)$ mempunyai bentuk hubungan sebesar 0,03. Hal ini menandakan adanya tingkat hubungan yang sangat rendah antara variabel strategi promosi dengan keputusan membeli. Hasil analisa Sig. (2-tailed) sebesar 0,9 dan dibandingkan dengan taraf signifikan 1\%, dapat diartikan sebagai: $0,9>0,09$, maka tidak signifikan, artinya tidak terdapat pengaruh yang signifikan antara strategi promosi $\left(\mathrm{X}_{4}\right)$ terhadap keputusan membeli $(\mathrm{Y})$. 


\section{Saran}

Dengan melihat hasil analisa ternyata hanya variabel harga dan distribusi yang secara bersama-sama mempunyai hubungan dan signifikan dengan variabel keputusan pembelian produk Koran JualBeli, oleh karenanya pengembangan usaha Koran JualBeli sebaiknya berfokus pada dua variabel ini. Penetapan harga yang tepat sesuai pasar sasaran dan perluasan distribusi dapat menjadi alternalif pilihan kebijakan.

Selanjutnya perlu dilakukan kajian yang mendalam sebagai tindak lanjut hasil penelitian ini, sehingga didapatkan sebuah kajian komprehensif untuk melihat lebih jauh variabel-variabel lain yang belum diteliti dalam rangka menyempurnakan kebijakan perusahaan yang menyangkut pengembangan pemasaran produk Koran JualBeli.

\section{DAFTAR PUSTAKA}

Alma, Buchari., (2007). Manajemen Pemasaran dan Pemasaran Jasa, Alfabeta, Bandung.

Kotler, Philip and Keller, K., (2012), Marketing Management, 14th Edition, Pearson Prentice Hall.

Kotler, Philip and Armstrong, Gary., (2008), Principles of Marketing, 12th Edition, Prentice Hall, New Jersey.

Kotler, Philip. Ang, Swee Hoon. Leong, Siew Meng \& Tan, Chin Tiong (2004), Manajemen Pemasaran Sudut Pandang Asia (terjemahan), PT Indeks Kelompok Gramedia, Jakarta.

Mowen, John C \& Minor, Michael. 2001. Perilaku Konsumen. Edisi kelima. Jilid 1. Terjemahan oleh Lina Salim.2002. Jakarta: Erlangga.

Santoso, Singgih \& Tjiptono, Fandy (2002), Riset Pemasaran, Konsep dan Aplikasi Dengan SPSS, Cetakan kedua, Penerbit PT. Elex Media Komputindo, Jakarta.
Supranto J. (2006), Pengukuran Tingkat Kepuasan Pelanggan, Rineka Cipta, Jakarta.

Tjiptono, Fandy (2008), Strategi Pemasaran, Edisi Ketiga, Andi, Yogyakarta.

Tjiptono, Fandy (2005), Pemasaran Jasa, Bayemedia Publishing, Malang. 